\title{
БЛАГОДІЙНІСТЬ ЯК РЕЛІГІЙНО-ПРАВОВА КАТЕГОРІЯ В МУСУЛЬМАНСЬКОМУ Й ІУДЕЙСЬКОМУ ПРАВІ ТА III СУТНІСНI РИСИ В ЗАКОНОДАВСТВІ УКРАЇНИ
}

Тарановська А. О.

у статmі проаналізовано визначення поняття благодійності як складного і багатоаспектного явища в кількох вимірах: сочіальному та релігійно-правовому. Витоки провадження благодійної діяльності простежуються в багатьох світових релігійних вченнях. Автор звертає увагу на історичність та важливість благодійної діяльності, що здійснюється народами світу з давніх часів у різноманітних варіаціях залежно від цивілізаційного розвитку. Концептуальні основи благодійності безперечно мають релігійне коріння, яке з часом трансформувалось у межах факторного середовища. Зокрема, зазначається, що благодійність - це одна з фундаментальних доктрин іудейської релігійно-правової системи. У мусульманських країнах благодійність є частиною санкціонованої соціальної та правової політики держави. Автором досліджено загальні питання та особливості здійснення благодійної діяльності в межах релігійно-правових доктрин іудаїзму та ісламу. Іудейська цдака і мусульманській закят являють собою релігійні обов'язки, приписи, що закріплені у священних текстах іудаїзму й ісламу відповідно та справляються виключно вірянами. Окрім закяту, в мусульманській релігійно-правовій доктрині діє поняття «садака» як абсолютно добровільне справляння милостині у необмеженій кількості на власний розсуд людини. Цдака i закят можна розглядати як визначальні фактори національного єднання та спорідненості.

Крім того, у статті зазначаються концептуальні моменти провадження благодійності в Україні відповідно до чинного законодавства, наводяться статистичні дані щодо стану благодійності в Україні за останне n'ятиріччя. Визначено актуальність цієї проблематики в контексті розбудови громадянського суспільства й наукову новизну цієї теми; приділено увагу взаємодії історичної складової частини благодійної діяльності з сучасністю.

Ключові слова: благодійність, іудейське право, мусульманське право, законодавство України, суспільство.

Taranovska A. O. The charity as a religious and legal category in Muslim and Jewish law and its essential features in the legislation of Ukraine

The article analyzes the definition of "charity" as a multisided phenomenon in the social, religious and legal dimensions. The origins of charity can be traced in many world religious teachings. The author draws attention to the historicity and importance of charity carried out by the peoples of the world since ancient times in variations depending of their civilizational development. The author researches the characteristic features of the category "charity" from the viewpoint of its religious and judicial nature in several variations: "tzedakah" as the Jewish concept of charitable activities, "zakat" as Muslim alms-tax, "sadaqah" as material assistance, paid by Muslims voluntarily at their discretion. The paper identifies the specific role of charity as one of the fundamental features of Jewish and Muslim religious and legal doctrines. It also pays attention to the sacred texts of Judaism and Islam, and especially, the author quotes the propositions concerning carrying out charity by believers. The author concludes the religious roots of charity, which has transformed over time, depending on the factor environment.

Moreover, the article refers to the conceptual moments of charity in Ukraine, according to the legislation in force. The author also considers the general aspects of charitable activities in Ukraine, taking into account the value experience of the two Abrahamic religions of the world. The paper notes to the relevance and scientific novelty of this topic; it pays attention the interaction of the historical component of charity with the present time, as for the Ukrainian society it is appropriate to consider the problem of establishing charitable activities as an essential socio-economic functional vector of the state for national unity in conditions of political instability.

Key words: charity, jewish and muslim law, Ukrainian legislation, society.

Постановка проблеми та їі актуальність. 3 метою розбудови громадянського суспільства в нашій державі провадження благодійної діяльності $\epsilon$ актуальною темою для юридичної науки, оскільки має практичний аспект. 32015 р. питання меценатства в Україні набуло популярності, цьому сприяла низка політичних та економічних подій. На підтвердження цієї думки доречно навести статистичні дані, отримані

(C) Тарановська А. О., 2020 
в рамках загальнонаціональних досліджень, що проводились Фондом «Демократичні ініціативи» імені Ілька Кучеріва спільно з соціологічною службою Центру Разумкова, найвищого показника участь громадян у благодійній діяльності за часи незалежності України досягла після Революції гідності. Так, 47\% опитуваних у 2015 р. надавали грошову чи матеріальну допомогу конкретним людям чи організаціям. Далі цей відсоток із кожним роком знижується: 42\% - у 2016 р., 41\% у 2017 р., 38,5\% - у 2018 р. [10].

Під благодійністю слід розуміти можливість творити благо, здійснювати милосердні справи [1, с. 51].

У тлумачному словнику C.I. Ожегова поняття «благодійність» визначено як безкорислива та спрямована на суспільну допомогу діяльність певних осіб або організацій [2, с. 56].

Взагалі благодійність - це складне та багатоаспектне явище, що, безперечно, сформувалось під впливом релігійних норм. Витоки цього соціального феномена знаходяться у багатьох релігійних доктринах. 3 огляду на вищенаведене, доцільно розглянути поняття благодійності у релігійно-правовому вимірі з точки зору двох монотеїстичних світових релігій - іудаїзму та ісламу.

Як зазначалось, актуальність зазначеного питання полягає, перш за все, в тому, що для розбудови і якісного функціонування громадянського суспільства в Україні благодійна діяльність $\epsilon$ одним із пріоритетних напрямів, оскільки зменшує соціальну напругу, сприяє національній єдності та формує такі людські чесноти, як співчуття, милосердя, повага до ближнього, підтримка нужденного тощо.

Відповідно до Закону України «Про благодійну діяльність та благодійні організації» благодійна діяльність - це добровільна особиста та/або майнова допомога для досягнення визначених цим Законом цілей, що не передбачає одержання благодійником прибутку, а також сплати будьякої винагороди або компенсації благодійнику від імені або за дорученням набувача благодійної допомоги [3].

У науковій літературі існує думка, що благодійність - це переважно напрям діяльності релігійних організацій [4, с. 50].

Вважаємо за необхідне подискутувати з цього питання, оскільки благодійну діяльність проводять також світські організації, громадські об'єднання та окремі фізичні особи.

Доречно звернути увагу на той факт, що в Україні кількість благодійних організацій постійно зростає: станом на квітень 2019 р. офіційно зареєстровано 18557 благодійних організацій (далі - БО), у квітні 2018 р. - 17897 БО, у квітні 2017 р. - 17062 БО. Хоча,за твердженням Українського форуму благодійників, маємо справу з фіктивними організаціями, які діють лише на «папері», реальні цифри суттєво відрізняються: це приблизно 500-1000 благодійних організацій. Більшість коштів, отриманих від благодійної діяльності, спрямовується на охорону здоров'я українських громадян [5].

Важливо дослідити питання здійснення благодійної діяльності в межах іудейської релігійно-правової доктрини, зважаючи на те, що християнство (релігія, яку сповідує більшість українців, а саме 85\% населення, відповідно до даних Релігійно-інформаційної служби України) розвинулось під впливом іудаїзму і має з ним спільне коріння; також цікаво розглянути провадження благодійності з точки зору мусульманської релігійно-правової доктрини, оскільки кількість вірян ісламу зростає, нині це друга за чисельністю релігія світу.

Аналіз останніх досліджень i публікацій. Теоретичні та прикладні аспекти мусульманського права висвітлювали в наукових працях видатні дослідники-правники Л. Сюкіяйнен, В. Лубський, В. Борис, М. Лубська.

Питання феномена іудейського права, що збереглося в умовах тривалої бездержавності, неодноразово досліджувалось такими вченими, як Н. Переферкович, М. Елон, І. Шифман, М. Марченко, Д. Лук'янов, Г. Білорицький.

Феномен благодійності як індикатор соціокультурного стану спільноти вивчався А. Лядневою в межах дисертаційного дослідження з соціальної філософії та філософії історії.

І. Литвин розглядав благодійність як цивільно-правову категорію в доктринальному та законодавчому вимірі.

Проте поняття «благодійність» як релігійно-правова категорія в межах ісламу та/або іудаїзму не є поширеним об'єктом спеціального вивчення вітчизняних науковців.

Отже, необхідно наголосити, що зазначена тема $є$ актуальною та має ознаки наукової новизни.

Метою статті $\epsilon$ виявлення сутнісних особливостей провадження благодійної діяльності в іудейському та мусульманському праві. Крім того, варто звернути увагу на важливі аспекти цієї проблематики в українському законодавстві, зважаючи на історичний досвід таких релігійно-правових систем, як іудейська та мусульманська. 
Поставлена мета передбачає розв'язання низки конкретних завдань:

дослідити фундаментальні ознаки здійснення благодійності та проаналізувати схожі або відмінні особливості провадження благодійної діяльності в межах іудейської та мусульманської релігійно-правових доктрин;

окреслити сутнісні риси благодійності, що визначені в Законі України «Про благодійну діяльність та благодійні організації»;

сформувати та узагальнити отримані висновки із зазначеної теми.

Виклад основного матеріалу. Благодійність одна з фундаментальних доктрин іудейської релігійно-правової системи. Іудаїзм - найдавніша монотеїстична релігія, що зберіглася дотепер i $€$ складовою частиною двох інших світових релігій - християнства та ісламу [6, с. 128].

Якщо звернутись до джерел іудейського права, зокрема Тори (Священної Книги іудеїв, що своєю чергою складається з п'яти книг: Берешит, Шмот, Ваїкра, Бемідбар, Дварим), то знайдемо достатньо приписів щодо вчинення благодійності. Наприклад, у Книзі Дварим йдеться про те, що необхідно допомагати ближньому, оскільки сам Бог заохочує цю справу, благодійність являє собою атрибут Бога: «Розкрий руку свою братові твоєму» (15:11), «Не роби серце твоє жорстоким і не затискай руку твою перед братом твоїм нужденним» (15:7), «Господь допомагає сиротам і вдовам, любить переселенців, адже і ви самі були переселенцями на землі єгипетській» $(10: 18,19)$. У Книзі Йєшаягу, яка входить до Невіїм (другий розділ Танаху - Святого Письма іудаїзму), говориться, що радісний для Бога не день посту, а день, коли людина ділить свій хліб із голодним, приводить у дім бідного й одягає злиденного (58:6-8). У Книзі Естер (третій розділ Танаху - Ктувім) відправлення дарів нужденним розглядається як частина свята з приводу того, що єврейський народ оминула загроза загибелі від підлих інтриг із боку Амана (з цими подіями пов'язане єврейське свято Пурім, що святкується кожного року дотепер) [7].

Варто зазначити, що Танах (Святе Письмо іудаїзму, до якого власне й входить Тора, Невіїм та Ктувім) не містить конкретно оформленої та визначеної назви «благодійність» або «благодійна діяльність», а розглядається лише в теоретично-прикладному вимірі. Саме у Талмуді, в контексті вчинення благодійних справ, зустрічається поняття «цдака». Доцільно дослідити етимологію цього слова: «цдака» досить часто перекладається з івриту як «благодійність», проте якщо брати до уваги дослівний переклад, то маємо дещо інакше значення - справедливість, милостиня, праведність. Єврейські мудреці говорять, що кожного, хто жаліє інших, жаліє Всевишній, і навпаки, хто безсердечно ставиться до ближнього, не належить до нащадків Авраама. Іудейська релігійно-правова доктрина стверджує, що все те, що отримує людина, вона отримує від Бога, отже, Він $\epsilon$ господарем іï надбання. Цдака належить до 613 заповідей (міцвот), які має виконувати єврейський народ, адже це одна з основ, на яких стоїть світ. Свідчення щодо вчинення благодійності (цдаки) кодифіковані Маймонідом (рабі Моше бен Маймон) у XII-XIII ст. Необхідно навести основні положення та порядок справляння цдаки:

- бідний родич має перевагу щодо отримання благодійності порівняно 3 іншою, можливо, й злиденною людиною; людина єврейського походження має «пільги» в черговості отримання цдаки перед неєвреєм; бідні твого міста (поселення тощо) переважають над тими, хто живе на іншій території, за виключенням нужденних із земель Ізраїлю;

- жінки мають пріоритет у користуванні цдакою перед чоловіками;

розмір цдаки варіюється від 10 до 20\%, проте не варто віддавати понад 1/5 прибутку, щоб самому не стати нужденним та не притіснити власну родину (окремий випадок, коли людині, що помирає, дозволяється віддати до 1/3 частини прибутку або майна);

- найкращий варіант - здійснювати пожертву таємно, щоб той, хто отримує їі, не знав того, хто дає. Взагалі факт сплати/отримання цдаки не афішувався. Це досить просто обґрунтовується з боку психологічного комфорту бідняка, оскільки в момент прохання або отримання цдаки він певною мірою відчуває сором, полегшенню його емоційного стану сприяє таємність вчинення благодійної справи;

цдака збирається не менше ніж двома особами, а роздачою займається не менше трьох осіб; обов'язково ведеться облік бідних в єврейській общині;

той, хто отримує цдаку, також має виділяти невелику частину від неї на допомогу більш нужденному [8]. Цікаво, що отримання цдаки $є$ цілком законним, але вважається за необхідне вчиняти все залежне, щоб не звертатись до цього. Крім того, цдака передбачає не лише утримання грошових коштів, але й, наприклад, надати безпроцентну позику, допомогти з роботою, порадити прибуткову справу, сплатити за навчання 
дітей із бідних сімей, інвестувати кошти у певний проєкт тощо.

Згідно зі ст. 3 Закону України «Про благодійну діяльність та благодійні організації» сферами благодійної діяльності в Україні $є$ освіта, охорона здоров'я, екологія, охорона довкілля та захист тварин, запобігання природним і техногенним катастрофам та ліквідація їхніх наслідків, допомога постраждалим внаслідок катастроф, збройних конфліктів і нещасних випадків, а також біженцям та особам, які перебувають у складних життєвих обставинах, опіка і піклування, законне представництво та правова допомога, соціальний захист, соціальне забезпечення, соціальні послуги і подолання бідності, культура та мистецтво, охорона культурної спадщини, наука i наукові дослідження, спорт і фізична культура, права людини і громадянина та основоположні свободи, розвиток територіальних громад, розвиток міжнародної співпраці України, стимулювання економічного росту і розвитку економіки України та їі окремих регіонів та підвищення конкурентоспроможності України, сприяння здійсненню державних, регіональних, місцевих та міжнародних програм, спрямованих на поліпшення соціально-економічного становища в Україні, сприяння обороноздатності та мобілізаційній готовності країни, захисту населення у надзвичайних ситуаціях мирного і воєнного стану [3].

Як бачимо, $\epsilon$ певні спільні риси сфер здійснення благодійної діяльності: українське законодавство має досить розширений перелік цілей для благодійності.

Отже, на підставі вищевикладеного щодо іудейської концепції здійснення благодійної діяльності можна зробити такі висновки: благодійність, милостиня (цдака) - це не бажання, не право, а обов'язок, припис (міцвот), що заповідав Всевишній єврейському народові. Проте Талмуд розтлумачує варіативність сплати цдаки та перераховує особливі умови отримання, що дуже важливо для втілення іï в життя. Крім того, варто зазначити, що прикладний аспект є характерною ознакою іудейської релігійно-правової доктрини.

Розглянувши основні положення благодійності в межах «найстарішої» монотеїстичної світової релігії - іудаїзму, що суттєво вплинула на формування християнства, необхідно звернутись до вчення «наймолодшої» авраамічної релігії світу ісламу, з питанням щодо здійснення благодійної діяльності.

Враховуючи, що позиції ісламу є максимально незмінними з плином часу в державах, де ісламська релігійна доктрина $є$ панівною, варто зазна- чити, що благодійна діяльність у мусульманських країнах $\epsilon$ частиною санкціонованої соціальної та правової політики держави [9, с. 68].

Відповідно до релігійного вчення ісламу, Аллах (Господь) - милостивий та милосердний і такі вимоги ставить до всіх вірян-мусульман. На підтвердження вищевикладеної тези доцільно навести уривки 3 Корану (Священна Книга мусульман та основне джерело мусульманського права): «Ті, хто розтрачують своє майно на шляху Аллаха, схожі з зернятком, котре виростило сім колосків, в кожному колоссі - сто зерен. I Аллах подвоює, кому побажає. Воістину, Аллах всеогортаючий та Той, що знає!» (Сура 2:261), «Ті, хто витрачають своє майно на шляху Аллаха і потім те, що витрачено не супроводжується доріканнями та образами, їм - їх нагорода від Господа їх, i немає страху над ними, і не будуть вони опечалені» (Сура 2:262), «Ніколи не досягнете ви благочестя, допоки не будете витрачати те, що вам до вподоби. А щоб ви не утримали, Аллах про це знає» (Сура 3:92), «Бери з їх майна пожертву (закят), щоб очиститись ними та возвеличити їх. Молись за них, тому що твої молитви - спокій для них. Воістину. Аллах - Той, що слухає та Той, що знає» (Сура 9:103), « І стійте молитву, і давайте закят (з арабської мови «очищення»), і поклоніться з тими, хто кланяється!» (Сура 2:43) [10].

На особливу увагу заслуговує слово «закят», що зустрічається в Корані 60 разів, релігієзнавці досить часто говорять про нього як про «один із п'яти стовпів ісламу» (перший стовп - шахада, сповідування єдиного Бога, другий - намаз, щоденні молитви, третій - піст у місяць Рамадан, четвертий - сплата закяту, п'ятий - хадж, паломництво до Мекки). Якщо уважно дослідити текст Корану, то обґрунтування надзвичайної важливості закяту $\epsilon$ таким: той, хто заперечує існування та необхідність закяту, впадає в невіру, саме за допомогою його сплати мусульманин очищує душу та отримує молитовне заступництво від Пророка Мухаммеда перед Аллахом.

На думку вченої Дагестанського державного університету народного господарства Р. Халієвої, «закят» - це різновид ісламських податків, тобто різноманітні форми платежів або данина, що утримувались із населення мусульманських держав, склались у процесі арабських завоювань VII-VIII ст. н.е. з метою формування фінансової системи Халіфату, вкоренились із плином часу та не втрачають актуальності дотепер. Закят - це релігійний податок-милостиня, що має духовне значення та справляється з благодійною метою. 
У цьому і полягає сутнісна відмінність від іудейської цдаки: закят справляється з метою очищення душі та оновлення духовної рівноваги і вторинно як спосіб допомоги ближньому [11, с. 180].

У Корані міститься вичерпний перелік підстав, на яких утримується закят: «Пожертви призначені для бідняків, для тих, хто їх збирає та розподіляє, для тих, чиї серця хочуть завоювати, для викупу рабів, для боржників, для видатків на шляхи Аллаха, для мандрівників» (Сура 9:60) [10].

Згідно зі ст. 3 Закону України «Про благодійну діяльність та благодійні організації» благодійні організації не мають права надавати благодійну допомогу політичним партіям або від імені політичних партій, а також брати участь у виборчій агітації [3]. Цікавою є цитата 3 приводу того, що кошти від закяту можуть бути спрямовані на «завоювання сердець», йдеться про поширення «привабливості» ісламу в світі, а отже, і мусульманського права. Тобто можливий варіант виділення коштів від закяту на агітаційну діяльність релігійного спрямування.

У результаті дослідження проблематики здійснення благодійної діяльності в межах ісламської релігійно-правової доктрини варто звернути увагу, що, окрім закяту, існує таке поняття, як «садака». Розмежовуючи ці дві категорії, маємо зазначити обов'язковий характер сплати, визначений порядок, розмір та цілі закяту (так званий релігійний податок) та добровільність і необмеженість сплати садаки.

Закят сплачується один раз на рік зі встановленого виду майна:

- дорогоцінності (золото, срібло);

- орендна плата;

- банківські вклади;

- цінні папери;

- худоба (виключно молочна, племінна або з пасовища, у разі досягнення необхідної визначеної кількості);

- врожай (зерно та плоди);

- товари, призначені для продажу та за визначеною ціною;

- корисні копалини [11, с. 181].

Коран (Сура 2:264) застерігає щодо брехливої, уявної благодійності, йдеться про благодійну діяльність, яка здійснюється навмисне напоказ із чванливих та лицемірних мотивів, оскільки такі дії $\epsilon$ негідними для віруючих мусульман та караються Аллахом.

Висновки. Розглянувши фундаментальні основи здійснення благодійної діяльності в межах іудейської та ісламської релігійно-правових сис- тем, необхідно зазначити виявлені ознаки та особливості:

1) цдака і закят - це релігійний обов'язок, припис, що закріплений у священних текстах іудаїзму й ісламу відповідно та справляється виключно вірянами;

2) грошовий вимір цдаки і закяту є чітко регламентованим;

3) закят завжди був соціально-економічним інститутом держави;

4) цдака - це частина соціальної політики, що проводилась у межах єврейських общин в умовах довготривалої бездержавності;

5) окрім закяту, в мусульманській релігійно-правовій доктрині існує добровільне справляння милостині у необмеженій кількості на власний розсуд - «садака»;

6) поняття «закят» прямо вживається в Корані;

7) термін «цдака» не зустрічається в Танахові, 3'являється лише в Талмуді, проте з розгорнутим тлумаченням у прикладному значенні;

8) цдака не обов'язково надається особі єврейського походження, на відміну від закяту, що утримується виключно на користь мусульман;

9) у Корані надається вичерпний перелік цілей, на які витрачаються кошти, отримані від закяту;

10) цдака характеризується варіативністю благодійних дій (від частини майна до надання конкретних послуг);

11) цдака і закят є впливовими чинниками національної спорідненості.

Отже, варто зазначити, що благодійна діяльність здійснюється народами світу з давніх часів у різноманітних варіаціях залежно від цивілізаційного розвитку. Концептуальні основи благодійності, безперечно, мають релігійне коріння, яке з часом трансформувалось у межах факторного середовища. Крім того, благодійність можна розглядати як активну практичну форму гуманізму, інструмент впливу на суспільство, що має стати важливим соціально-економічним вектором діяльності держави задля національного єднання в умовах політичної нестабільності, тому не варто зневажати історичний досвід людства.

\section{Література}

1. Гладченко С. Історичні передумови благодійної діяльності релігійних організацій та церкви в Україні. Гілея: науковий вісник. 2015. Випуск 95. С. 51-54.

2. Ожегов С.И. Словарь русского языка / Ред. Шведовой Н.Ю. Москва, 1990. 542 с.

3. Про благодійну діяльність та благодійні організації : Закон України від 05.07.2012 р. № 5073-VI. Дата оновлення: 27.02.2020 p. URL: https://zakon. 
rada.gov.ua/laws/show/5073-17 (дата звернення: 23.08.2020).

4. Новіков В. До питання про благодійну діяльність релігійних організацій. Записки Львівського університету бізнесу та права. 2013. С. 50-53.

5. Пеліванова Н. Розвиток благодійності в Україні. 2019. URL: https://niss.gov.ua/doslidzhennya/ gromadyanske-suspilstvo/rozvitok-blagodiynosti-vukraini (дата звернення: 22.08.2020).

6. Лубський В., Теремко В., Лубська М. Релігієзнавство : підручник. 2011. 463 с.

7. TaHaX. Тора. Невиим. Ктувим. URL: https:// nev-tanah.info/tora (дата звернення: 22.08.2020).

8. Талмуд. Электронная еврейская энциклопедия. URL: https://eleven.co.il/ (дата звернення: 21.08.2020).

9. Кузнецова И. Формирование социального капитала мусульман: роль благотворительности. Россия и мусульманский мир. 2012. С. 64-77.
10. Коран. URL: https: / /librebook.me/quran (дата звернення: 22.08.2020).

11. Халиева Р. Исламские налоги. Актуальные вопросы экономических наук. 2014. С. 180-183.

12. Литвин І.В. Благодійність як цивільно-правова категорія: доктринальний вимір. Університетські записки. 2014. № 4. С. 104-112.

13. Ляднева А.В. Феномен благодійності як індикатор соціокультурного стану спільноти : автореф. дис. ... канд. філософ. наук : 09.00.03. Київ, 2017. 20 c.

14. Сюкияйнен Л. Основы теории исламского права. Москва, 2015. 170 с.

Тарановська А. О., аспірантка

Донецького юридичного інституту міністерства внутрішніх справ України 